\title{
FEDERAL ESTATE AND GIFT TAXATION
}

\author{
ROBERT KRAMER
}

THE year $1957^{1}$ was not a particularly notable one so far as developments in the field of federal gift and estate taxes are concerned. Indeed, with considerable justification one might contend that what did not happen during 1957 was more significant than what did happen. The Supreme Court did not hand down a single decision in this field.' Congress enacted no legislation affecting these taxes. ${ }^{3}$ The Treasury did not issue the gift and estate tax regulations under the 1954 Code. The year 1958 promises to tell a different story. The Supreme Court almost certainly will decide one important case. ${ }^{5}$ A tax measure of some sort seems virtually certain of enactment by Congress. ${ }^{\circ}$ And the Treasury presumably will not delay issuance of the long awaited regulations for another full year.

Judging by the provisions of the proposed Technical Amendments Bill of 1957,7 as reported out of the House Ways and Means Committee, there was little indication that Congress was ready to undertake any drastic revision of the gift and estate tax sections of the 1954 Code. Of the five provisions relating to these taxes in the bill, three were of minor interest. ${ }^{8}$ One, section 57, adds a new section 2517 to

Robert Kramer is Professor of Law at Duke University and Visiting Professor at New York University School of Law.

1 This paper is written with an editorial deadline of October 15, 1957.

2 The Court denied petitions for certiorari in several cases. Shedd v. Commissioner, 352 U.S. 1024 (1957); Heringer v. Commissioner, 352 U.S. 927 (1956); Bowden v. Commissioner, 352 U.S. 916 (1956); DuPont v. Commissioner, 352 U.S. 87S (1956); Sweet v. Commissioner, 352 U.S. 878 (1956); Woolsey v. Commissioner, 352 U.S. 832 (1956).

3 The House Ways and Means Committee has submitted a favorable report on HR. 8381, 85th Cong., 1st Sess. (1957), the Technical Amendments Bill of 1957, which contains six sections affecting gift and estate tases.

4 Proposed estate tax regulations were issued on October 16, 1956; proposed gift tax regulations were issued on January 3, 1957. See Johnson, The Proposed Federal Estate Tax Regulations, 34 Taxes 822 (1956) ; Kirby, Proposed Estate Tar Regulations, 96 Trusts \& Estates 12 (1957); Nossaman, The Proposed Gift Tar Regulations, 96 Trusts \& Estates 108 (1957) ; Rodman, The Proposed Estate Tax Regulations-Estates of Nonresidents Not Citizens, 96 Trusts \& Estates 79 (1957); Young, Proposed Estate Tax Regulations, 95 Trusts \& Estates 1080 (1956); 1956 Ann. Survey Am. L. 145, 32 N.Y.U.L. Rev. 739 (1957).

5 Fidelity-Philadelphia Trust Co. v. Smith, 241 F.2d 690 (3d Cir.), cert. granted, 354 U.S. 921 (1957). See Merchant's Nat'l Bank v. United States, 246 F.2d 410 (7th Cir.), cert. denied, 355 U.S. 881 (1957); Goodman v. Granger, 243 F.2d 264 (3d Cir.), cert. denied, 355 U.S. 835 (1957); Estate of Pipe v. Commissioner, 241 F.2d 210 (7th Cir.), cert. denied, 355 U.S. 814 (1957).

6 See note 3 supra and notes 7-8 infra.

7 H.R. 8381, 85th Cong., 1st Sess. (1957).

8 Section 53 extends the period of limitation for filing claims for the credit for state death taxes under $\S 2011$ (c) of the 1954 Code (and also $\S 813(\mathrm{~b})$ of the 1939 Code). Section 54 extends the period within which credit for state death taxes may be claimed 
the 1954 Code to exempt from a gift tax an irrevocable election by an employee to have benefits paid to a survivor under certain pension, stock bonus, or profit-sharing plans. ${ }^{9}$ In general, the benefits under section 2517 are to be similar to those conferred for the estate tax under section 2039 (c). The exemption extends only to "qualified plans" and only to benefits attributable to the employer's contributions.

Section 56 of the proposed bill is an attempt to deal with the controversial subject of the premium payment test for insurance on the life of a decedent payable to beneficiaries other than his estate. The 1954 Code completely eliminated this test, and required inclusion of such insurance only if the decedent (either alone or in conjunction with others) possessed incidents of ownership in the policy at his death. The 1939 Code, as amended in 1942, had required inclusion of such insurance if decedent either had incidents of ownership or if he had paid premiums on the insurance ${ }^{10}$ (only that part of the insurance proceeds proportionate to the part of the premiums paid by the insured was taxed). Under section 56 , insurance on decedent's life payable to beneficiaries other than his estate would be included in his gross estate not only if he possessed incidents of ownership at his death, but also under the following conditions. If at any time within five years of death (1) the policy was either purchased on decedent's life after June 26,1957 , or the decedent possessed incidents of ownership in the policy after June 26,1957, and (2) during the five-year period decedent paid any premiums directly or indirectly on the policy. The amount includible under this section is the same proportion of the insurance proceeds as the ratio of the premiums or consideration paid by decedent during the five-year period to the total of all premiums or consideration ever paid for the policy. The section applies only to estates of decedents dying after the enactment of the bill.

The bill hardly restores effectively the premium payment test. In fact, it is hard to discover the reasoning behind this provision. Why was a five-year period selected? If an insurance policy or incidents of ownership are transferred by decedent in contemplation of death three

on certain reversionary or remainder interests under $\S 2015$ (and $\$ 927$ of the 1939 Code) and also the period for payment of the estate tax on such interests under $\S 6163$ (and $\$ \S 925-26$ of the 1939 Code) when undue hardship is shown. Section 55 makes a slight technical change in $\$ 2039$ (c) (2). There have been several bills passed in the House to amend the 1954 Code. H.R. 8881, 85th Cong., 1st Sess. (1957), \& 812 (e)(1)(F); H.R. 8887, 85th Cong., 1st Sess. (1957), \& 814; H.R. 5938, 85th Cong., 1st Sess. (1957), $\$ 812(\mathrm{e})(1)(\mathrm{D})$.

9 Under present law such an irrevocable designation of benciciary, if made inter vivos, under a qualified pension plan is a taxable gift to the extent of the benefits paid for by the employer as well as the employee. Section 2039(c) exempts from the estate tax benefits paid for by the employer in a similar case. See Lowndes and Kramer, Federal Estate and Gift Taxes 653-57 (1956).

10 See id. at 276-79. 
years before death, the entire proceeds of the insurance are taxable under section 2035, even if decedent paid no premiums. If the insured paid any premiums in contemplation of death within three years of death, a part of the proceeds are includible in his gross estate under section 2035, even if he did not possess incidents of ownership within this period.11

Turning from congressional proposals to the decisions of the courts, one encounters little that is novel during the period under review. A quick glance at the decisions, following in general the order of the 1954 Code, will confirm this assertion. Of course, there are no decisions as yet actually interpreting the 1954 Code, and several years may well elapse before there are. However, in the majority of instances it is doubtful, unless otherwise noted hereafter, whether the result reached under the 1939 Code differs from that under the 1954 Code. $^{12}$

In the contemplation of death area the Government continued to have little success in the litigated cases. ${ }^{13}$ Reading the opinions in these and similar decisions of prior years, we can take comfort from the amazing zest for life and unconcern with death shown by our senior citizens regardless of their age and health.

In Bartlett v. United States ${ }^{14}$ the court of claims decided that a trust for a decedent-grantor for her life, with remainder to her "heirs," did not create an express reversion in the grantor. The court determined that under New York law ${ }^{15}$ the doctrine of worthier title

11 Where premiums are paid in contemplation of death within three years of death, the amount of the taxable transfer is uncertain. Is it (1) the amount of the premiums paid within three years of death, or (2) a part of the policy proceeds proportionate to the ratio between the premiums paid by the insured within three years of death, and the total premiums paid for the policy, or (3) the total amount of the policy proceeds, or (4) the difference betwreen the proceeds and the cash surrender value at the start of the three-year period? See id. at 289,859 . Section 56 should certainly be amended to specify exactly what amount is taxable if, because of premium payments within three years of death in contemplation of death, insurance proceeds are taxable under both $\S 56$ and $\S 2035$.

12 In the discussion hereafter references are made to sections of the 1954 Code even though the court decisions actually involved the parallel sections of the 1939 Code, except as otherwise noted.

13 Duncan v. United States, 148 F. Supp. 264 (D. Mass. 1957) (no contemplation of death; decedent's age 87); Union \& New Haven Trust Co. v. United States, 57-1 CCH Tax Cases II 11680 (D. Conn. 1957) (age 69; part in contemplation of death); Browarsly" v. Granger, 148 F. Supp. 665 (W.D. Pa. 1956) (no contemplation of death); E. Corsy Henry, P-H 1957 T.C. Mem. Dec. II 57079 (held in contemplation of death; decedent's age 92); May Hicks Sheldon, 27 T.C. 194 (1956) (decedent's age so; no contemplation of death); Edmund W. Mudge, 27 T.C. 188 (1956) (not in contemplation of death; decedent's age 65; unfunded insurance trust). See Rea, Life Insurance Gifts Subject to Rules on Contemplation of Death, $6 \mathrm{~J}$. Taxation 30 (1957). 1956).

14146 F. Supp. 719 (Ct. Cl. 1956). Cf. Costin v. Cripe, 235 F.2d 162 (7th Cir.

15 Doctor v. Hughes, 225 N.Y. 305, 122 N.E. 221 (1919). 
did not create a reversion. Despite the apparently contrary position of the regulations, ${ }^{16}$ one may wonder if the reversion would be an express one even if a reversion had been created by the doctrine of worthier title.

Cardeza $v$. United States ${ }^{17}$ involved a situation where the result might differ under the 1954 Code, even though the language of the 1939 Code does not differ materially from the relevant sections of the 1954 Code. Decedent had a reserved power of appointment over part of the corpus of a trust which she could exercise only in the event that she survived all her children and their issue. She died at age 85 , survived by one son, age 64 , without issue but able to procreate, married to a woman age 59. The court ruled that decedent's reversionary interest had no ascertainable value under applicable valuation principles, because of the possibility that her son might marry another woman and have issue. Therefore, the court held, relying upon a conference committee report $t^{18}$ and the 1939 Code regulations ${ }^{10}$ which so stated, that the reversion was to be considered as having a value of zero. However, the committee reports ${ }^{20}$ in discussing section 2037 of the 1954 Code take a different position on this point, stating that a reversionary interest is not to be considered as having no value simply because it cannot be valued actuarially, provided that the property could have reverted to decedent under "contingencies that were not remote." Thus, under the 1954 Code, if the reversionary interest cannot be accurately valued, the Government, not the taxpayer, may prevail.

Trusts under which the income and/or corpus are payable to the grantor solely in the discretion of a third person still threaten to open up gaps between the estate and gift taxes so that such a transfer may escape both. Such transfers are generally held not taxable under section 2038, based upon a literal reading of the Code which applies only where the power is reserved to the grantor and others. This results in applying section 2038 when the grantor can revoke only with the consent of an adverse party, such as a beneficiary, but not applying the section when a trustee alone with no substantial adverse interest may revoke. ${ }^{21}$ Such a result is hard to defend. Recently, the Tax Court has held that if the trustee may be required to pay part or

10 Proposed Estate Tax Reg. \$ 20.2037-1(g) (2).

17 57-1 CCH Tax Cases โ1 11681 (E.D. Pa. 1957).

18 Conf. Committee Report, H.R. Rep. No. 1412, 81st Cong., 1st Sess. (1949), 1949-2 Cum. Bull. 295, 297-98.

10 U.S. Treas. Reg. 105, \& 81.17 (c) (1) (1951).

20 H.R. Rep. No. 1337, 83d Cong., 2d Sess. A314 (1954); S. Rep. No. 1622, 83d Cong., 2d Sess. 469 (1954). Cf. Proposed Estate Tax Reg. \& 20.2037-1(c) (3).

21 Lowndes and Kramer, op. cit. supra note 9, at 179-82. See Proposed Estate Tax Reg. $§ 20.2038-1$ (a) (3). 
all of the income and/or corpus to the grantor, the transfer is taxable to that extent under section 2036 on the ground that the grantor has retained the right to possession of the income for his life. ${ }^{22}$ However, the seventh circuit has reversed one of these Tax Court decisions. ${ }^{23}$ The Tax Court had ruled that under local law the grantor's creditors could reach his entire interest in the trust, which was therefore taxable, because the trustee was required to pay the grantor both $\$ 100$ a month, and, in the discretion of the trustee, additional income not exceeding the entire income of the trust. The court of appeals interpreted local law as not allowing creditors to reach the grantor's interest in the trust in excess of $\$ 100$ a month (the court held taxable only that part of the corpus required to produce the $\$ 100$ a month). The court also stated that even if the creditors of the grantor could reach the entire income, the right of the creditors was a right in third persons, not in the grantor, and therefore not subject to section 2036.94 If the court of appeals is correct-and its reasoning seems persuasive-the gift tax aspect of the problem must be considered.

Consistent with its reasoning in the estate tax case that such a transfer is subject to the estate tax under section 2036, the Tax Court in several decisions has held that a similar trust is not subject to the gift tax on the ground that the grantor had not made a complete transfer. ${ }^{25}$ Thus where a grantor transferred property in trust and gave the trustees power to pay her such income and corpus as they in their discretion deemed desirable for her comfortable well-being and enjoyment, the Tax Court ${ }^{28}$ held there was no taxable gift of either income or corpus. Relying on a prior decision to the same effect, ${ }^{27}$ the court said there was no gift of income because the grantor's creditors under local law could reach her income interest. Relying upon another prior decision ${ }^{28}$ in a case distinguishable on its facts (the grantor had a power to revoke the entire trust which she could exercise alone under certain conditions) the Tax Court held there was no taxable gift of the corpus because of the trustee's unrestricted power to invade corpus for

22 Edgar M. Uhl, 25 T.C. 22 (1955), rev'd, 241 F.2d 867 (7th Cir. 1957); Carolyn P. Boardman, 20 T.C. 871 (1953).

23 Edgar M. Uhl, supra note 22.

24 Proposed Estate Tax Reg. § 20.2036-1(b) (3) excludes from § 2036 a power over income held solely by a person other than the grantor.

25 Sarah G. Vander Weele, 27 T.C. 340 (1957); Alice Spsulding Paolozzi, 23 T.C. 182 (1954).

26 Sarah G. Vander Weele, supra note 25.

27 Alice Spaulding Paolozzi, 23 T.C. 182 (1954).

28 Christianna K. Gramm, 17 T.C. 1063 (1951). Cf. Robinette v. Helvering, 318 U.S. 184 (1943); Smith v. Shaughnessy, 318 U.S. 176 (1943); Rev. Rul. 54-537, 1954-2 Cum. Bull. 316; Rev. Rul. 54-538, 1954-2 Cum. Bull. 316 (distinguishing the Gramm case because there the corpus and income were so small that it was virtually certain the grantor would in fact be paid the entire corpus). 
the grantor. If, as seems probable, such a transfer is not taxable under the estate tax, then clearly it should be taxable under the gift tax. ${ }^{20}$ Generally, the courts have held that a transfer is complete for the gift tax if the power to alter or revoke is lodged solely in third persons other than the grantor. ${ }^{30}$ If the power in the third person is a contingent power-one subject to a real contingency not wholly within the grantor's control-the possibility that the transfer is still not subject to the estate tax should certainly make it taxable under the gift tax. ${ }^{31}$

The long-mooted problem of the combination annuity and single premium life insurance policy is apparently headed for a definitive ruling. In Fidelity-Philadelphia Trust Co. v. Smith ${ }^{32}$ the third circuit, reversing a district court, held the proceeds of a single premium life insurance policy taxable under section 2036, even though the insured decedent had retained no incidents of ownership in the policy, which had been assigned to the beneficiaries, her children. In order to obtain the policies from the insurer, the decedent had purchased at the same time a single life annuity on her life, the combined premiums for the insurance and annuity equalling $11 / 10$ of the face amount of the policy. Such policies are not considered as life insurance, but as investments. ${ }^{33}$ Following decisions of the Tax Court and two other circuits, ${ }^{34}$ the court held the policy proceeds taxable. The court refused to follow the contrary decision of the seventh circuit, which had been affirmed by an equally divided Supreme Court. ${ }^{36}$ Since the Supreme Court opinion does not reveal how the individual Justices voted, and since the membership of the Court has since changed considerably, it is impossible to predict how the present Court, which has granted certiorari, will decide this question. Actually, as the third circuit reasoned, the annuity and policy seem indivisible, even if sepa-

29 Proposed Gift Tax Reg. \& 25.2511-2(b) states that if the trustee has full discretion to pay trust income to the donor or accumulate it, there is no gift at all if the donor retains a testamentary power to appoint the remainder among his descendants. The cntire gift is a complete transfer if the donor retains no testamentary power and the remainder goes to $\mathrm{X}$, but if the exercise of the trustee's power in favor of the donor is governed by a fixed standard, enforceable by the donor, there is no gift to the extent of the ascertainable value of the rights thus retained by the donor.

30 Lowndes and Kramer, op. cit. supra note 9, at 697-98.

31 Id. at 706-13. Proposed Estate Tax Reg. \$§ 20.2038-1(b), 20.2036-1(b)(3), exclude such a contingent power from a tax under $\$ 2038$, but indicate it may be taxable under $\$ 2036$.

32241 F.2d 690 (3d Cir.), cert. granted, 354 U.S. 921 (1957), 25 Gco. Wash. L. Rev. 721 .

33 Helvering v. Le Gierse, 312 U.S. 531 (1941).

34 Conway v. Glenn, 193 F.2d 965 (6th Cir. 1952); Burr v. Commissioner, 156 F.2d 871 (2d Cir.), cert. denied, 329 U.S. 785 (1946); Cora C. Reynolds, 45 B.T.A. 44 (1941). 35 Bohnen v. Harrison, 199 F.2d 492 (7th Cir. 1952), aff'd by an cqually divided court, 345 U.S. 946 (1953). 
rate contracts. They represent simply a deposit of the premiums from both contracts with the insurer with a reservation of the income from this amount to the insured during his life. ${ }^{30}$

Employee annuity problems still plague the courts under the 1939 Code, and some of them, at least, may be far from solved under section 2039 of the 1954 Code. Thus, in Libbey v. United States ${ }^{37}$ decedent was in fact receiving annuity payments after retirement under an annuity purchased for him by his employer. The payments were to continue for ten years, with the surviving widow entitled to the unpaid balance if decedent died before the end of the ten-year period, as he did. Decedent had an option, which he did not exercise, to convert the ten-year annuity to a single life or joint and survivor annuity before his actual retirement. The court ruled the benefits payable to his widow were not taxable because there had been no transfer of them by decedent to her. Since decedent was actually receiving the annuity payments at his death, the Treasury apparently regards the survivor's benefits as taxable under section 2039 on the ground that there was an annuity here "payable to the decedent" under a "form of contract or agreement."

In Molter $v$. United States ${ }^{39}$ decedent's widow received two years' salary from his employer at his death under a survivorship benefit plan. The employer had reserved the right to revoke or alter the plan at any time. The court ruled the payments to the widow were not taxable

36 The analogy to the retained life interest is not, however, entirely satisfactory. Ordinarily, if decedent retains a life interest in property, the property is taxable to his estate under $\S 2036$ even if the remaindermen sell or dispose of their interests prior to his death. However, if in the combination annuity-life insurance situation, the beneficiaries of the life insurance surrender the policies for their cash value before the insured's death, the policies are not included in the insured's estate at his death. Lillie G. Hutchinson, 20 T.C. 749 (1953).

37147 F. Supp. 383 (N.D. Cal. 1956). In Adeline S. Davis, 27 T.C. 378 (1956), decedent was receiving annuity payments before death, had elected to reccive a joint and survivor annuity, and retained until death the right to revole or change the clection with the consent of the insurer. His employer had paid for the annuity. The Tax Court held decedent had made a transfer, which was taxable under $\S \S 2036$ and 2038 beeause of his power to revoke the election. See Winton, Two Estate Planning Devices: Life Insurance Trusts; Employees Death Benefits, 7 J. Taxation 52 (1957); Bilder, Death Benefits Paid Under an Express Contract, 34 Taxes 529 (1956); Note, Estate Taxation of Employec Death Benefits, 66 Yale L.J. 1217 (1957).

38 Proposed Estate Tax Reg. \& 20.2039-1(b) (example 2). Section 2039 specifies that it applies to an annuity or payment receivable by a beneficiary "by reason of surviving the decedent." If the refund is payable to the wife only if she survives the employer, there is no difficulty here. If the refund is payable to the wife or to her estate, irrespective of whether she survives her husband, it may possibly be argued that the refund is not receivable by the wife "by reason of surviving the decedent," because there is no survivorship requirement for the refund beneficiary.

39146 F. Supp. 497 (E.D.Y.Y. 1956). 
because decedent had no interest which he could transfer to anyone. Under the language of section 2039 such a survivor death benefit raises several difficult problems. First, is there any contract or agreement here, since there is no legal obligation on the employer at any time to pay the benefits to the survivor-beneficiary? Even if there is a legal obligation to make payments to the deceased employee in the form of his salary while he works, section 2039 may require that payments both to the employee and to the survivor be made pursuant to a contract or agreement. ${ }^{40}$ Second, is there any annuity or payment payable to the decedent or which he possessed the right to receive prior to death? The only payment to decedent in this case is his salary. If he died before retirement and while receiving his salary, perhaps his salary satisfies the statutory requirement. ${ }^{41}$ If he had retired before death and ceased to receive a salary or other payment from his former employer, it is hard to find any payment payable to him or which he possessed the right to receive. Third, even if decedent's salary is a payment to him under section 2039, is it a payment for the requisite statutory period: "for his life or for any period not ascertainable without reference to his death or for any period which does not in fact end before his death"? If he died before retirement and while receiving his salary, perhaps the salary is a payment to him for a period which does not in fact end before his death. If he died after retirement and while not receiving his salary, it is difficult to see how the required statutory period is met. ${ }^{42}$

Family annuities pose equally hard problems. Thus in one case $e^{40}$ decedent transferred property worth over $\$ 96,000$ to her two children who promised to pay her during her life the entire income from the property, and also to make up any deficiency if the annual income ever

40 The Proposed Estate Tax Reg. $\$ 20.2039-1$ (b) (example 4) indicates that if an employer "consistently" pays benefits to survivors, even when not legally obligated to do so, they may be considered as being payable pursuant to a contract or agreement. This example of the regulations also indicates that, apart from this circumstance, benefits voluntarily paid a survivor-beneficiary by an employer of the deceased are not taxable under $\$ 2039$ because not paid pursuant to a contract or agreement.

41 See Lewis, The Estate Tax 66 n.15, 69 n.31 (Practising Law Institute 1957).

42 The Proposed Estate Tax Reg. § 20.2039-1(b) (example 5) indicates that tho survivor benefits are not taxed under $\$ 2039$ if decedent had retired before death and ceased to receive a salary. If decedent at death has any rights to change or revolie the beneficiary, the benefits may be taxed under $\$ 2038$, or if he could realize on the benefits by assigning them for value, they might be taxed under $\$ 2041$. The committce reports indicate that if decedent had not retired and was receiving a salary when he died, the survivor benefits are taxable under $\$ 2039$, at least if the employer was legally obligated to pay them. H.R. Rep. No. 1337, 83d Cong., 2d Sess. A315 (example 4) (1954); S. Rep. No. 1622, 83d Cong., 2d Sess. 470 (example 4) (1954).

See note 38 supra.

43 Greene v. United States, 237 F.2d 848 (7th Cir, 1956). 
fell below $\$ 3000$ (which it never did). Reversing the district court, the seventh circuit held the decedent had in effect retained a life interest in the transferred property falling under section 2036. The form of the transaction was such that the court had no difficulty in deciding that there was a retained life estate and not an outright purchase of an annuity for $\$ 96,000$ or the purchase of an annuity for part of the $\$ 96,000$ transferred, with an outright gift of the rest. The court also rejected the argument that the transfer was made for full and adequate consideration, but remanded the case for a determination of the value of the contingent obligation of the transferees to make good any deficiency in income below $\$ 3000$ annually. Since the income apparently never did fall below $\$ 3000$, the court of appeals evidently considered that the valuation of the contingent obligation should be made as of the time of the transfer, and not as of the date of decedent's death.

On this point the decision is opposed to that in Nourse v. Riddelt" by a California district court. Decedent here, when seventy-two years old, together with her children, created a trust from which she received the income for life, with remainders to her children. She transferred about $\$ 165,000$ to the trust, and her children about $\$ 283,000$. The court first ruled that the transaction amounted to a transfer by decedent of her remainder interest in the $\$ 165,000$ for a life interest in the $\$ 283,000$. Such a view seems a rather questionable one, for the atmosphere of the creation of the trust is one of mutual gifts among a family rather than of bargaining. ${ }^{45}$ The court further held that the life interest in the $\$ 283,000$ constituted adequate and full consideration for the transfer of the remainder interest to the children. To this reasoning there are two difficulties apparently overlooked by the court. First, if the purpose of the requirement of consideration here is to prevent depletion of the estate of the decedent, was there any consideration since all decedent acquired was a life interest not taxable at her death ${ }^{46}$ This question should be answered in the affirmative, for decedent did receive consideration in the form of a life income or right of support (assuming a fair price was paid for the annuity), just as if she had used all her assets to purchase a single life annuity for herself from a commercial company. Of course, any unconsumed portions of

14143 F. Supp. 759 (S.D. Cal. 1956), 70 Harv. L. Rev. 1486 (1957), 10 Okla. L. Rev. 228 (1957).

45 For discussion of the dificult problems of consideration in intrafamily transfers, see Lewis, The Alimony Trust; When and How to Use this Valuable but Hazardous (Taxwise) Device, $6 \mathrm{~J}$. Taxation 365 (1957); Pedrick, Familial Obligations and Federal Taxation: A Modest Suggestion, 51 Nw. U.L. Rev. 53 (1956). See also Comments, Federal Taxation of Alimony Payments and Property Settlements, 29 Roclyy Mrt. L. Rev. 368 (1957); Tax Aspects of Alimony Trusts, 66 Yale L.J. 881 (1957).

46 Lowndes and Kramer, op. cit. supra note 9, at 310-17. 
her life income will be taxable to her estate at her death. Second, the value of the consideration received by decedent even if it equalled the value of the remainder interest she gave her children, did not equal the entire value $(\$ 165,000)$ of the property in which she retained the life interest. The last question raises a problem which has not as yet received a definite or satisfactory answer. Where decedent reserves a string or power over transferred property, what is full and adequate consideration sufficient to remove the transfer from the estate tax? Is it: (1) consideration equal to the entire value of the property which would be included in his gross estate because of the reserved string; (2) consideration equal only to the value of the part of the property originally transferred, less the value of the retained interest; or (3) consideration equal simply to the value of the reserved string, if the grantor later releases the reserved string? In other words, must the consideration equal the value of what is transferred, or the value of what may escape the estate tax because of the transfer? The question has been raised so far mainly in cases involving joint interests. ${ }^{47}$

The Nourse case seems wrong on another point involving the method of valuing the life interest received by the decedent in her children's property. The Treasury valued the life interest on the basis of the life expectancy of the decedent at the time of the transfer, according to the tables of the regulations. ${ }^{48}$ In fact, decedent lived far longer than her life expectancy according to these tables. The court rejected the tables as outdated, but instead of valuing the life interest according to more modern tables, valued it on the basis of hindsight, using the actual time decedent lived after the transfer. The court relied on Tax Court decisions which did reject the Treasury tables, but which did not use hindsight. ${ }^{49}$ The court clearly erred in not valuing

47 Sullivan's Estate v. Commissioner, 175 F.2d 657 (9th Cir. 1949); Baltimore Nat'l Bank v. United States, 136 F. Supp. 642 (D. Md. 1955); Commonwealth Trust Co. v. Driscoll, 50 F. Supp. 949 (N.D. Pa.), aff'd per curiam, 137 F.2d 653 (3d Cir. 1943), cert. denied, 321 U.S. 764 (1944). Cf. Mildred Irene Siegel, 26 T.C. 743 (1956); Chase Nat'l Bank, 25 T.C. 617 (1955). See Lowndes and Kramer, op. cit. supra note 9, at 314-17.

48 In Bowden v. Commissioner, 234 F.2d 937 (5th Cir.), cert. denied, 352 U.S. 916 (1956), the grantor transferred property to a trust, reserving for himself a life income of $\$ 400$ a month from the trust. The court upheld the Treasury's valuation of the remainder and life interests by use of the tables in the regulations, and refused to value the retained interest of the grantor on the basis of what a similar commercial annuity would cost.

49 John P. Hoelzel, 28 T.C. 384 (1957); Shauck E. Barlow, 13 T.C. 760 (1949); Nellie H. Jennings, 10 T.C. 323 (1948); John Halliday Denbigh, 7 T.C. 387 (1946). In all these cases, where a life tenant was seriously ill when decedent died, the Tax Court used the apparent life expectancy of the sick life tenant at the time of decedent's death to value the life estate. The court did not value the interest on the basis of how long the life tenant actually lived. Since annuitants often live longer than others, there may be some basis for valuing an annuity by special life expectancy tables. 
what the decedent gave and received on the basis of her life expectancy at the time of the inter vivos transfer and on the basis of the value of the properties at that time. ${ }^{50}$ Another problem not adverted to by the court was also present. The property transferred to the trust must be valued as of decedent's death, not as of the time of transfer, but the consideration received by decedent is valued as of the time of transfer. Suppose the decedent's property is worth $\$ 100,000$ at the time of the transfer, and $\$ 200,000$ at her death, and the consideration is valued at $\$ 25,000$ as of the time of transfer. Is the net value for the gross estate in excess of the consideration equal to $\$ 175,000$ ( $\$ 200,000$ less $\$ 25,000)^{51}$ or $\$ 150,000(75,000 / 100,000 \times 200,000)$ ? $^{52}$ Plainly the second approach giving an answer of $\$ 150,000$ is the correct one, since the test should be what proportion of the transferred property did decedent receive consideration for at the time of the original transfer.

Goodman v. Granger ${ }^{53}$ illustrates further aspects of the difficulties in these cases. There the employer by contract agreed to pay the employee or his estate for fifteen years after death or retirement certain annual "contingent compensation." Payments were contingent upon the deceased duly performing certain services, not engaging in a competing business, and not having earnings in excess of a certain amount. The lower court held that the decedent's rights under the contract were valueless when valued, as they should be, immediately before his death. The court of appeals, reversing, held the contract rights should be valued immediately after death, on the basis of an annuity for a fifteen-year term, using the tables of the regulations. Both courts agreed that decedent's contract rights were property includible in his gross estate under section 2033. The court of appeals referred to the fact that in the case of a joint and survivor annuity the Treasury method, which it had approved, is to use the cost to the survivor at decedent's death of a comparable single life annuity for the survivor based upon the survivor's age at that time $e^{\text {os }}$ (or in some cases the value is figured from the Treasury tables using the survivor's life expectancy at the time of decedent's death)..$^{50}$ The court perhaps

50 Ithaca Trust Co. v. United States, 279 U.S. 151 (1929).

51 So held in William Schoenheit, 14 B.T.A. 33 (1928), modified, 44 F.2d 476 (4th Cir. 1930). Cf. D. G. McDonald, 19 T.C. 672, 690 (1953), aff'd, 225 F.2d 621 (sth Cir. 1955), cert. denied, 350 U.S. 965 (1956).

52 So held in Josephus Parker, P-H 1942 B.T.A. Mem. Dec. If 42228. Cf. Helvering v. United States Trust Co., 111 F.2d 576, 579 (2d Cir.), cert. denied, 311 U.S. 678 (1940). The court used this method in the Nourse case, discussed in text at note 44 supra.

53243 F.2d 264 (3d Cir.), cert. denied, 355 U.S. 835 (1957). See also Christiemin v. Manning, 138 F. Supp. 923 (D.N.J. 1956).

54 Rev. Rul. 55-302, 1955-1 Cum. Bull. 446. Cf. Mearkle's Estate v. Commissioner, 129 F.2d 386, 388 (3d Cir. 1942); Christiernin v. Mranning, supra note 53; John L. Walker, 8 T.C. 1107 (1947); Judson C. Welliver, 8 T.C. 165, 172 (1947).

55 Cf. Grant v. Smyth, 123 F. Supp. 771 (N.D. Cal. 1954), aff'd, 226 F.2d 407 (9th Cir. 1955). 
overlooked the fact that another method has also been used, namely, the difference between (1) the cost of a comparable joint and survivor annuity just before decedent's death, and (2) the cost of a single life annuity for decedent just before his death, with no survivorship feature. ${ }^{58}$

Other valuation problems were also present during $1957 .{ }^{\circ 7}$ The use of replacement cost.to value insurance policies on the life of someone other than decedent which are included in decedent's gross estate has been approved. ${ }^{58}$ The insurance is valued in the same way as under the gift tax. Cash surrender value alone is not the criterion. In Delia Craweford McGehe ${ }^{59}$ decedent made several outright gifts of stock in contemplation of death. After the gifts, the corporation, which had never issued dividends in cash or property, but always capitalized current earnings and declared stock dividends, issued stock dividends before decedent died. Most of the stock dividends represented earnings subsequent to the gifts. A majority of the Tax Court decided that the stock dividends should be included in the gross estate as part of the transfer in contemplation of death. If the transfer had been in trust, and dividends in cash or property had been accumulated or added to corpus, there is authority for excluding them. ${ }^{60}$ When the transfer is outright, the dividends if paid in property or cash clearly would not be included. On the other hand, if no stock dividends had been declared, the earnings, as reflected in the estate tax valuation at decedent's death of the original stock, would clearly be subject to the estate tax. ${ }^{61}$ Thus the argument may well be made that the decisive factor here is whether the earnings have actually been severed from the corporation, and the reasoning of Eisner v. Macomber ${ }^{62}$ would be followed in that stock dividends which represent a mere proliferation

58 Frederick J. Twogood, 15 T.C. 989, 992 (1950), aff'd, 194 F.2d 627 (2d Cir. 1952). Cf. William J. Higgs, 12 T.C. 280 (1949), rev'd, 184 F.2d 427, 428 n.1 (3d Cir. 1950).

57 See Fitts v. Commissioner, 237 F.2d 729 (8th Cir. 1956) (approving Tax Court valuation of stock in a close family corporation, based upon financial data), $17 \mathrm{La}$. $\mathrm{L}$. Rev. 862 (1957); Cullers v. Commissioner, 237 F.2d 611 (8th Cir. 1956) (rejecting Tax Court valuation of farm); Hughes, "Blockage" in Valuation of Assets for Federal Tax Purposes, 25 Fordham L. Rev. 702 (1957).

58 DuPont v. Commissioner, 233 F.2d 210 (3d Cir.), cert. denied, 352 U.S. 878 (1956). Cf. Proposed Estate Tax Reg. \$ 20.2031-8.

5928 T.C. 412 (1957), 57 Colum. L. Rev. 1037. See 54 Harv. L. Rev. 512 (1941).

60 Jacob Gidwitz, 14 T.C. 1263 (1950), aff'd, 196 F.2d 813 (7th Cir. 1952); James

E. Frizzell, 9 T.C. 979 (1947), reconsidered, 11 T.C. 576 (1948), aff'd sub nom. Burns v. Commissioner, 177 F.2d 739 (5th Cir. 1949). But cf. Wasserman v. Commissioner, 139 F.2d 778 (1st Cir. 1944); Igleheart v. Commissioner, 77 F.2d 704 (5th Cir. 1935); B. H. Kroger, P-H 1943 T.C. Mem. Dec. If 43392, aff'd on this point, 145 F.2d 901 (6th Cir. 1944), cert. denied, 324 U.S. 866 (1945).

61 Milliken v. United States, 283 U.S. 15 (1931).

62252 U.S. 189 (1920). 
of capital under that case should be subject to the estate tax here, particularly since they will escape any income tax. The majority opinion argued that the stock transferred represented a proportional interest in the value of the business, and the stock dividends did not change the proportional interest. Apparently the majority were applying the income tax tests of the 1939 Code and arguing that if the stock dividend was not taxable as income under the income tax it was includible in the gross estate. True, all the dividends represented earnings, and, with one exception, earnings after the transfer in contemplation of death, but the earnings apparently were not severed from the stock by the stock dividends. ${ }^{63}$ Of course, it is possible that by a lavish use of stock dividends after stock was transferred in contemplation of death, the value of the stock might be substantially reduced by the time decedent died. There was no evidence of such a tax evasion scheme here. The value of the stock transferred did not lessen after issuance of the stock dividends. The same problems may arise, in the case of stock dividends paid within a year after decedent's death, if the alternate valuation date is used. Here the regulations ${ }^{\text {of }}$ attempt to prevent tax evasion by distribution of corporate assets after decedent's death, and also flatly state that all stock dividends declared within a year of decedent's death are taxable if the alternate valuation date is used.

The third circuit has ruled that under the 1942 act an exercise of a power of appointment in favor of the same persons and in the same amounts as would take in default of appointment is a taxable exercise of the power under section 2041. ${ }^{\text {o5 }}$ This is true even if local state law regards the property as not passing under the exercise of the power.

The past year saw a decided increase in litigation over the marital deduction. In view of the complexities of this deduction and of language used in trusts and wills designed to take advantage of it to the fullest extent, there is little risk in predicting that future years will see more and more litigation over this deduction. Some problems of the 1939 Code may be cured by changes in the 1954 Code. Under the 1954 Code, unlike the 1939 Code, the surviving spouse need not have the entire income from the trust or insurance proceeds and a power of appointment over the entire trust or the entire proceeds in order to qualify the interest for the marital deduction as an exception to the

63 Cf. Igleheart v. Commissioner, 77 F.2d 704 (5th Cir. 1935) ; B. H. Kroger, P-H 1943 T.C. Mem. Dec. II 43392, aff'd on this point, 145 F.2d 901 (6th Cir. 1944), cert. denied, 324 U.S. 866 (1945). See Lowndes and Kramer, op. cit. supra note 9, at 465-74. 64 Proposed Estate Tas Reg. $\$ 20.2032-1$ (d)(1)(iv). Cf. MLaass v. Higgins, 312 U.S. 443 (1941).

65 Keating v. Mayer, 236 F.2d 478 (3d Cir. 1956); Thompson v. United States, 148 F. Supp. 910 (E.D. Pa. 1957). See Proposed Estate Tax Reg. $\$ 20.2041-1$ (d). 
terminable interest rule. ${ }^{60}$ So, too, under the 1954 Code, unlike the 1939 Code, the transfer of the life estate with the power of appointment to the surviving spouse need no longer be made in trust in order to qualify for the marital deduction under the exception to the terminable interest rule. Thus it is no longer necessary in order to obtain a marital deduction to attempt to convert a legal life estate with a power into a fee simple under local state law, or into a resulting trust. ${ }^{07}$

More difficulty has been encountered as to the nature of the power which the surviving spouse must have with the life estate in order to qualify for the marital deduction under the exception to the terminable interest rule. What if the spouse has an unlimited power to invade or consume corpus during her lifetime, but all corpus not consumed at her death goes to designated beneficiaries? The Tax Court, ${ }^{08}$ over a dissent, has held such a power sufficient for the marital deduction; the second circuit, ${ }^{69}$ also with a dissent, has made a contrary ruling, stressing that although the spouse could invade and consume the entire corpus (so that she had a taxable power of appointment under section 2041), she could not dispose of property unconsumed at her death. The distinction of the court of appeals seems tenuous

66 Shedd v. Commissioner, 237 F.2d 345 (9th Cir. 1956), cert. denied, 352 U.S. 1024 (1957); Sweet v. Commissioner, 234 F.2d 401 (10th Cir.), cert. denied, 352 U.S. 878 (1956); Blanchard H. Stallworth, P-H 1957 T.C. Mem. Dec. If 57168; William H. A. Warner, P-H 1956 T.C. Mem. Dec. If 56278. The House has passed a bill, H.R. 8381, 85th Cong., 1st Sess. (1957), supra note 7, retroactively eliminating this requirement of the 1939 Code that the life interest and power must apply to the entire trust. Cf. Reilly v. Commissioner, 239 F.2d 797 (3d Cir. 1957), 35 N.C.L. Rev. 558, 43 Va. L. Rev. 587, where insurance proceeds were payable for ten years certain to the surviving spouse, and thereafter to her for life, but if she died within the ten-year period, the remaining proceeds were payable to the children. Reversing the Tax Court, the court of appeals allowed the marital deduction for the actuarial value of the contingent life annuity. The court of appeals ruled that the insurance proceeds should be divided into two funds, one of which qualified for the marital dcduction even under the 1939 Code. Compare the position of the Treasury in Rev. Rul. 54-553, 1954-2 Cum. Bull. 303, with U.S. Treas. Reg. 105, \& 81.47a(d) (1949).

67 Estate of Pipe v. Commissioner, 241 F.2d 210 (2d Cir.), cert. denied, 355 U.S. 814 (1957), 57 Colum. L. Rev. 893, 5 Buffalo L. Rev. 344 (1956); Matteson v. United States, 147 F. Supp. 535 (N.D.N.Y.), aff'd on other grounds, 240 F.2d 517 (2d Cir. 1956); Harriet C. Evilsizor, 27 T.C. 710 (1957). See Anderson, The Marital Deduction and Equalization under the Federal Estate and Gift Taxes between Common Law and Community Property States, 54 Mich. L. Rev. 1087 (1956). The House has passed a bill, H.R. 8381, supra note 7, retroactively eliminating this requirement of a trust from the 1939 Code.

68 Harry A. Ellis, 26 T.C. 694 (1956). But cf. Wallace S. Howell, 28 T.C. 1193 (1957) ; Theodore G. Tarver, 26 T.C. 490 (1956).

69 Estate of Pipe v. Commissioner, 241 F.2d 210 (2d Cir.), cert. denicd, 355 U.S. 814 (1957). Under the Proposed Estate Tax Reg. \& 20.2056(b) $-5(\mathrm{~g})(3)$, the power of invasion is sufficient if it is an "unrestricted" one "exercisable at any time during her life to use all or any part of the property ... and to dispose of it in any manner, including the power to dispose of it by gift ...." 
and dubious, since it is clear that a power of appointment is sufficient here even if it is exercisable only by deed (during the surviving spouse's entire life) and not by will. ${ }^{70}$

Where the surviving spouse elects to take against the decedent's will and to take her statutory share in decedent's estate, her statutory interest is regarded as passing to her from decedent. ${ }^{71}$ However, if it is a terminable interest, no marital deduction is allowed for it. ${ }^{72}$ Frequently it is difficult to ascertain whether the statutory interest of the surviving spouse is a terminable interest or not under local law. ${ }^{73}$

In Proctor D. Rensenhouse $e^{74}$ the Tax Court held that amounts expended for the support of a surviving spouse during the settlement of the estate-the widow's allowance-were not property passing from decedent to the surviving spouse under local law and did not therefore qualify for the marital deduction. The holding seems contrary to congressional committee reports ${ }^{75}$ and a prior service ruling ${ }^{70}$ which assumed the deductibility of such amounts if they were not terminable interests. The majority opinion argued that such an interest is not dower, is not a bequest, and is not inherited. Local law, of course, may require a different result if it treats the allowance as part of dower or a statutory substitute. ${ }^{77}$

Cases continue to litigate the question of whether the interest to the surviving spouse passes free of or subject to its pro rata share of the federal estate tax. If the interest is subject to the tax, the amount of the marital deduction is decreased by the amount of the tax on the interest. $^{78}$ The testator, of course, can eliminate the problem com-

70 Int. Rev. Code of $1954, \S 2056$ (b) (5), states that the power is sufficient "whether exercisable by will or during life . ..." A bill passed by the House, H.R. 8381, supre note 7 , retroactively amends the 1939 Code to state expressly that an unrestricted power of invasion in a surviving spouse is sufficient here even if she has no power to dispose by will of property unconsumed at her death.

71 Lowndes and Kramer, op. cit. supra note 9 , at 382 .

72 Id. at 386.

73 Crosby v. United States, 151 F. Supp. 497 (N.D. Fla. 1957) (Als.; marital deduction allowed); Traders Nat'l Bank v. United States, 148 F. Supp. 278 (W.D. Mo. 1956), aff'd, 248 F.2d 667 (8th Cir. 1957) (Mo.; marital deduction allowed).

7427 T.C. 107 (1956), 25 Geo. Wash. L. Rev. 704 (1957).

75 S. Rep. No. 2375, 81st Cong., 2d Sess., 1950-2 Cum. Bull. 483, 525; H.R. Rep. No. 2319, 81st Cong., 2d Sess., 1950-2 Cum. Bull. 380, 478.

76 Rev. Rul. 83, 1953-1 Cum. Bull. 395. Cf. Rev. Rul. 56-26, 1956 Int. Rev. Bull. No. 5, at 10. Proposed Estate Tax Reg. $\$ 20.2056$ (e)-(2)(a) seems to assume that, if not a terminable interest, such an allowance is property which passes from decedent to his spouse.

i7 Cf. King v. Wiseman, 147 F. Supp. 156 (W.D. Okla. 1956) (deduction allowed under Oklahoma law; query if the interest under Oklahoma law really differed from that involved under Michigan law in the Rensenhouse case).

78 Rose Gerber Jaeger, 27 T.C. 863 (1957) (Ohio law; spouse's share subject to tax). See also Merchants Nat'I Bank v. United States, 246 F.2d 410 (7th Cir.), cert. denied, 355 U.S. 881 (1957) (Indiana; same result); Babcock v. Commissioner, 234 F.2d 837 (3d Cir. 1956) (Pa. law; contra result). 
pletely by suitable language in his will, but unfortunately many wills are either silent on the point or contain ambiguous language. In construing the admittedly ambiguous language of one will disposing of a $\$ 14,000,000$ estate, the state court judge frankly adopted the reasoning that a man of such wealth must have intended to avoid all taxes possible and therefore would wish the widow's interest to pass tax free to her since this would reduce the total tax on the estate by almost $\$ 1,300,0000^{79}$

The valuation placed upon a partnership interest by an agreement among the partners enabling the surviving partner to purchase decedent's interest in the firm without payment for good will was upheld in a case where there was evidence of real bargaining between the parties involved..$^{80}$ Perhaps the most important decisions in this field were those which ruled that premium payments by closed corporations for insurance on the lives of shareholders were not taxable as dividends and income to the shareholders. ${ }^{81}$

Under the gift tax, litigation was almost wholly centered upon the annual exclusion. There was widespread comment ${ }^{82}$ upon whether a gift to a closed corporation is a gift to the corporation or to the shareholders. There was general agreement that if the donor is a shareholder, the value of the gift should be reduced proportionately in accordance with the proportion his stock represents of the entire issued stock. There was disagreement whether the basis of the reduction was (1) that the gift is to the shareholders and a man cannot make a gift

70 Case v. Roebling, 42 N.J. Super. 545, 127 A.2d 409 (Ch. 1956). Cf. Matter of Burnett, 43 N.J. Super. 534, 129 A.2d 321 (Ch. 1957).

80 Mandel v. Sturr, 57-1 CCH Tax Cases I 11688 (S.D.N.Y. 1957). See Mackay, Effects of 1954 Code and Regulations on Stock Purchase Agreements, 96 Trusts \& Estates 121, 204 (1957) ; Pennell, Tax Aspects of Retiring an Interest in a Small Company with a Buy-Sell Agreement, 6 J. Taxation 116 (1957); Swados, Death and Nonsense: The Decline and Fall of the Buy-Sell Agreement, 26 Fordham L. Rev. 189 (1957).

81 Prunier v. Commissioner, 248 F.2d 818 (1st Cir. 1957), reversing 28 T.C. 19 (proceeds to be turned over to corporation for purpose of purchasing deceased's stock); Casale v. Commissioner, 247 F.2d 440 (2d Cir. 1957), reversing 26 T.C. 1020 (1956) (proceeds payable to corporation but an equal amount to be paid to stockholder as deferred compensation), Comment, 33 N.Y.U.L. Rev. 89 (1958). See Freyburger, How Proposed Regulations Affect Taxation of Insurance Transfers and Death Bencfits, $5 \mathrm{~J}$. Taxation 44 (1956); Lawthers, Prunier Offers No Threat to a Sound Insured Buyout Plan, 7 J. Taxation 2 (1957); Lawthers, Weakness in Casale Decision: Insolvency Could Destroy Benefit to Owner-Employee, 5 J. Taxation 342 (1956); Lawthers, Tho Individual Life Insurance Policy Issued in Connection with a Qualified Employec Trust, 35 Taxes 173 (1957); Swados, supra note 80; Taylor and Maier, Sanders Case Again Emphasizes Care Needed in Agreements Funded by Insurance, 7 J. Taxation 68 (1957).

82 The case provoking the comment was Heringer v. Commissioner, 235 F.2d 149 (9th Cir.), cert. denied, 352 U.S. 927 (1956), noted in 57 Colum. L. Rev. 240 (1957), 6 Duke B.J. 150 (1957), 29 Rocky Mt. L. Rev. 134 (1956), 9 Stan. L. Rcv. 806 (1957), 4 U.C.L.A.L. Rev. 289 (1957). Cf. Proposed Gift Tax Reg. \$ 25.2511-1(g)(1). See 52 Nw. U.L. Rev. 135 (1957). 
to himself; ${ }^{83}$ (2) that the donee is the corporation, but the donor receives partial consideration for the transfer because of the resulting increase in the value of his own stock; or (3) that the donee is the corporation but the gift is partially incomplete because of the donor's stock ownership. There was sharp disagreement whether if the donees were the shareholders, any annual exclusion should be allowed. The problem is whether the donee shareholder receives a future interest for which no exclusion is allowed. Presumably no one donee (unless a majority stockholder), acting alone, could obtain the amount of the gift directly by dividends or liquidation of the corporation-the consent of the other donees would be required..$^{84}$ A donee to some extent could obtain the present value of the gift by selling his stock, but the owner of a reversion has no present interest even if he can sell his reversion..$^{85}$

Gifts to minors continue to plague the courts under the 1939 Code. The line often seems to be drawn so fine as to be almost invisible when the problem arises of what does or does not qualify for the exclusion here. One can only hope that section 2503 (c) of the 1954 Code may avoid such fruitless litigation. Thus, in George $W$. Perkins $^{86}$ the Tax Court allowed the exclusion when the minor beneficiaries, their parents, or their guardians had the right at any time to receive all or any part of the trust income or principal. The parents were supporting the children, and no guardians had been appointed except in one case. Where no such right to demand income or corpus existed but the trustee was merely authorized to pay income and corpus, the exclusions were denied by the Tax Court, even when the trustees were given the same powers as general guardians. ${ }^{87}$ The fourth circuit reached a contrary result in a similar situation. ${ }^{89}$

The widespread adoption by states of the Model Custodian Act

83 This seems to be the view of the Proposed Gift Tax Reg., supra note 82.

$84 \mathrm{~A}$ gift is a future interest if there are several donees and no one donee may obtain present enjoyment of the gift without the consent of the other donees. Ryerson v. United States, 312 U.S. 405 (1941); Skouras v. Commissioner, 188 F.2d 831 (2d Cir. 1951), affirming 14 T.C. 523 (1950); Jennie Brody, 19 T.C. 126 (1952); Nashville Trust Co., P-H 1943 T.C. Mem. Dec. I 43485. Cf. Howe v. United States, 142 F.2d 310 (7th Cir.), cert. denied, 324 U.S. 841 (1944); John MI. Smyth, P-H 1943 T.C. Mfem. Dec. If 43211.

85 See Lowndes and Kramer, op. cit. supra note 9, at 763-64, 767, 785-\$6.

8627 T.C. 601 (1956). Cf. Munger v. United States, 154 F. Supp. 417 (N.D. Als. 1957). See Bronston, State and Federal Taration: Gifts To or For Mlinors, 95 Trusts \& Estates 934 (1956); Rogers, Forbes and Smith, Recent Changes in the Rules for Gifts to Minors (How the Trouble Has Been Cleared Up), 17 U. Pitt. L. Rev. 585 (1956).

87 Abraham M. Katz, 27 T.C. 783 (1957). Other decisions denying exclusions for gifts to minors: Herrmann v. Commissioner, 235 F.2d 440 (5th Cir. 1956); Glenn v. Pitts, 145 F. Supp. 779 (W.D.S.C. 1956); William Goehner, 28 T.C. 542 (1957); Josephine B. Crane, P-H 1957 T.C. Mem. Dec. I 57003.

88 United States v. Baker, 236 F.2d 317 (4th Cir. 1956). 
for gifts to minors may give rise to tax problems. ${ }^{80}$ Under this act, the custodian of the gift is authorized in his sole discretion to apply principal and income for the minor's support, education, use, and benefit, the unexpended income and principal to be paid to the donee at the age of twenty-one or to his estate if he dies before then. A gift under this act does qualify for the annual exclusion as a present interest..$^{90}$ However, there may be undesirable gift, estate, and income ${ }^{01}$ tax consequences for the donor, the custodian, or the parents. Thus, the Treasury $^{92}$ has ruled that a transfer by a donor to himself as custodian for a minor donee pursuant to this act is includible under section 2038 in the donor's gross estate if he dies while acting as custodian and while the donee is alive and under twenty-one. Such transfers also seem subject to section 2036(a)(2), and, if the donor has a legal obligation to support the donee, to section 2036(a)(1). Even if the donor is not the custodian, if he is a parent of the minor donee, the transfer possibly might be included in his gross estate under section 2036 if the transfer discharges his obligation to support the donee..$^{93}$ If the parent is custodian but not the donor, the transfer might be included in his gross estate under section 2041, on the ground that his power as custodian is taxable because it may be used to discharge his obligation to support the minor donee and therefore is exercisable in favor of himself or his creditors.

89 Schlesinger, When and How to Use the New Statutory Custodian for Gifts to Minors, 5 J. Taxation 263 (1956); Tenney, Tax Considerations in Gifts to Minors Made Under New State Custodian Laws, 5 J. Taxation 348 (1956); Widmark, Tax Considerations Under Model Act; Security Gifts to Minors, 95 Trusts \& Estates 698 (1956); Notes, 69 Harv. L. Rev. 1476 (1956) ; 31 St. John's L. Rev. 155 (1956).

90 Rev. Rul. 56-86, 1956 Int. Rev. Bull. No. 11, at 11.

91 See Rev. Rul. 56-484, 1956 Int. Rev. Bull. No. 40, at 8.

92 Rev. Rul. 57-366, 1957 Int. Rev. Bull. No. 32, at 20.

93 See Lowndes and Kramer, op. cit. supra note 9, at 145-47. 